\title{
Genetic relationships among populations of Mytilus desolationis from Kerguelen, M. edulis from the North Atlantic and M. galloprovincialis from the Mediterranean
}

\author{
Michel Blot ${ }^{1}$, Catherine Thiriot-Quiévreux ${ }^{2}$, Jacques Soyer ${ }^{1}$ \\ ' Université Pierre et Marie Curie, Laboratoire Arago, UA 117, F-66650 Banyuls-sur-Mer, France \\ ${ }^{2}$ Université Pierre et Marie Curie, Station Zoologique, F-06230 Villeiranche-sur-Mer, France
}

\begin{abstract}
The mussel Mytilus desolationis Lamy 1936, which constitutes large populations in the Kerguelen Islands, a highly isolated archipelago, is generally considered an endemic species on the basis of morphological data. Cross-matching of electromorphs of $M$. desolationis with those of $M$. edulis and $M$. galloprovincialis demonstrated that the 29 electromorphs recorded in $M$. desolationis at 12 loci were identified in the 38 electromorphs observed in European populations at the same loci. Nine rare electromorphs are lacking in the Kerguelen mussel but no diagnostic locus was detected in the present study. Allozymic frequencies at 10 enzymatic loci from 2 populations of $M$. desolationis are analysed and compared with the data of Skibinski et al. $(1980,1983)$ on 4 populations of $M$. edulis and 3 populations of M. galloprovincialis. Correspondence analysis shows that 2 levels of allozymic frequency variations can be distinguished among the 9 populations: one level corresponding to a 'taxonomic' differentiation among these forms, the other corresponding to a population level within the taxa and more related to the environment. A phenogram illustrates genetic relationchips among $M$. desolationis, ivi. gällopevincialis and $M$. edulis, and the level of isolation of $M$. desolationis is discussed in terms of rare allozymes. Results suggest identification of $M$. desolationis as a semi-species in the super-species Mytilus edulis, inhabiting a low gene flow environment and subjected to high selective pressure.
\end{abstract}

\section{INTRODUCTION}

Species of the bivalve genus Mytilus vary greatly in shape, colour and the thickness of their valves. Many names have been applied to the various forms with differing morphology and geographical origin (SootRyen 1955). The distinction between species of Mytilus has become more acute following recent studies: Gosling (1984) reviewed the systematic status of Mytilus galloprovincialis in western Europe and concluded 'that the evidence from morphological, electrophoretic, cytological, immunological and artificial hybridization studies now indicates that $M$. galloprovincialis is closely related to $M$. edulis but does not merit the rank of full species. It would appear from the evidence to date that $M$ galloprovincialis is a variety, ecotype or perhaps subspecies of the larger Mytilus edulis species complex' (Gosling 1984, p. 566).

In the Kerguelen Islands $\left(70^{\circ} \mathrm{E}, 49^{\circ} \mathrm{S}\right.$; Southern
Indian Ocean), the genus Mytilus is represented by Mytilus desolationis Lamy 1936 (= M. kerguelensis Fletcher 1938) considered to be endemic to that archipelago. Electrophoretic polymorphism and allozyme frequencies at 10 loci have been previously studied in 4 populations of $M$. desolationis which comprise 2 genetically different groups, one in the large Gulf of Morbihan, the other along the external coasts of the archipelago (Blot et al. 1987). Contingent genetic specificities of $M$. desolationis must now be sought to determine the level of endemism of this marine benthic organism, drastically isolated from any continents in a subantarctic insular system.

In the present article, relationships between Mytilus desolationis, $M$. edulis and $M$. galloprovincialis are analysed from electrophoretic data. Relative electrophoretic mobilities at 12 enzymatic loci are compared and allozyme frequencies are used to study genetic differentiation between and within each form. 


\section{MATERIAL AND METHODS}

\section{Electrophoretic mobilities}

Sampling. To appreciate the level of enzymatic polymorphism of the little-known taxon Mytilus desolationis, 1000 individuals, of a size ranging from 2 to $90 \mathrm{~mm}$, were collected at low tide in different locations in the Kerguelen Islands (see Blot et al. 1987 for description of locations).

For Mytilus galloprovincialis, 60 specimens were collected at Banyuls (French Mediterranean coast) from a cultivated population on floating ropes in October 1986. Sampled mussels were adults of mean size $55 \mathrm{~mm}$.

For Mytilus edulis, 60 specimens were collected at Charron (French Atlantic coast) from cultivated populations on 'Bouchots' in October 1986. Sampled mussels were adults of mean size $45 \mathrm{~mm}$.

Electrophoresis. After each sampling, the adductor muscle and the digestive gland were dissected and deep-frozen $\left(-70^{\circ} \mathrm{C}\right)$. After homogenization with a glass rod, the samples were centrifuged at $12000 \times \mathrm{g}$ for $5 \mathrm{~min}$. Starch gel electrophoresis was performed after the methods of Ahmad et al. (1977). Staining methods of Brewer (1970) were used. Good resolution was obtained from the following enzymatic systems: Glycerophosphate dehydrogenase (GPD EC 1.1.1.8.), Glutamate oxaloacetate transaminase (GOT EC 2.6.1.1.), Leucine aminopeptidase (LAP EC 3.4.11,-), Malate dehydrogenase (MDH EC 1.1.1.37.), Phosphogluconate dehydrogenase (PGD EC 1.1.1.49.), Glucosephosphate isomerase (PGI EC 5.3.1.9.), Phosphoglucomutase (PGM EC 2.7.5.1.), Tetrazolium oxydase (TO EC 1.15.1.1.) and Xanthine dehydrogenase (XDH EC 1.2.3.2.). The Acid phosphatase (ACP EC 3.1.3.1.), Esterase (EST EC 3.1.1.1.) and Isocitrate dehydrogenase (ICD EC 1.1.1.42.) systems did not give publishable results.

Crossmatching. Each electromorph observed in the samples of Mytilus desolationis was recorded as a standard electromorph and was compared on same electrophoretic runs to the electromorphs of 40 specimens of $M$. galloprovincialis from Banyuls and 40 specimens of $M$. edulis from Charron, or 60 specimens at some loci, when observation of the electrophoretic mobility of a rare electromorph was needed. The electromorphs were then identified according to nomenclatures of Ahmad \& Beardmore (1976), Skibinski et al. (1980), and Skibinski et al. (1983).

In Mytilus desolationis, with a sample size of 1000 specimens, all the electromorphs occuring in the archipelago at a frequency higher than 0.000025 may be observed, at least once as heterozygote, with a binomial probability of 0.95 . In $M$. galloprovincialis and
$M$. edulis, with a sample size of 40 , the same law of probability gives a limit-frequency of 0.04 , and at the sample size of 60 a limit-frequency of 0.025

\section{Allozyme frequencies}

Populations. For Mytilus desolationis, 2 populations, each characterizing one of the 2 genetical groups previously demonstrated (Blot et al. 1987) were chosen: 80 adult mussels ( 60 to $80 \mathrm{~mm}$ length) were collected at low tide in January 1986 in Bossière Fjord (Gulf of Morbihan; mussel bank sheltered from western swells, with lower salinity than that of open sea) and Larose Bay (external coast; mussels in crevices of exposed rocks and in intertidal pools with ocean salinity).

For Mytilus galloprovincialis in the Mediterranean Sea, literature data were taken for Gibraltar and Venice (Skibinski et al. 1980) and for the Black Sea (Skibinski et al. 1983).

For Mytilus edulis, literature data were taken for Wales, UK (Skibinski et al. 1980), and for Long Island, Woods Hole and New Bristol, USA (Skibinski et al. 1983).

Electrophoresis. Electrophoretic methods performed to estimate allozyme frequencies in Kerguelen populations were the same as above. Data on the MDH allozymic frequencies in Mytilus edulis and M. galloprovincialis were not complete in the literature and thus could not be included in the comparison of populations.

Correspondence analysis. Data reduction of the contingency table of allozyme frequencies was performed by correspondence analysis (Guttman 1959, Benzecri 1969, Hill 1974, Lebart \& Fénelon 1975), using the software of Yagolnitzer \& Tabet (1985) to determine the contribution of each allozyme to the population differentiation. The advantage of this method is that populations and allozymes are represented in the same multidimensional space. Projection of the maximum inertia of the clouds of points determines the orientation of Axis I. Axis II maximizes the projection of inertia on a line perpendicular to Axis I. Axis III maximizes the projection of inertia on a line perpendicular to Plane I-II, and so on. Each point is defined by its polar coordinates where correlation to an axis is the angle and contribution to the axis is the projection of the distance from origin on this axis.

Genetic distance. Nei's distance is the most commonly used in biochemical systematics, it measures the accumulated number of gene substitutions per locus' (Nei 1972). Rogers (1986) compared several genetic distances and concluded that Euclidean distances (Sokal \& Rolhf 1963, Rogers 1972, Chardy 1980) are more adapted to closely related populations. Euclidean distances verify the properties of a genetic distance as 
defined in Gregorius (1978), Rogers (1984) and Katz \& Goux (1986). In addition, contrary to Nei's distance, no biological assumptions are needed (such as no selection or migration). The Euclidean distance is expressed as:

$$
D_{j k}=\sqrt{\sum_{i=1}^{N}\left(X_{i j}-X_{i k}\right)^{2}}
$$

where $N=$ total number of electromorphs; $X_{i j}$ and $X_{i k}=$ frequencies of the $i$ th electromorph in the populations $j$ and $k$. A dendrogram of genetic distances was constructed using the unweighted pair-group method of cluster analysis (UPGMA; Sneath \& Sokal 1973).

\section{RESULTS}

\section{Electrophoretic mobilities}

Electromorphs observed in our samples of the 3 forms and electromorphs described by Ahmad \& Beardmore (1976), Skibinski et al. (1980) and Skibinski et al. (1983) are given in Table 1. GOT, LAP and MDH show 2 loci where No. 2 is the more anodal (Ahmad \& Beardmore 1976). Following this rule, the LAP1 and LAP2 previously described in Blot et al. (1987) are now named LAP2 and LAP1 respectively. Twenty-nine standard electromorphs were observed at the 12 loci in the 1000 specimens of Mytilus desolationis analysed. The electrophoretic mobilities were the same as in the samples from Banyuls (M. galloprovinciais) and Charron (M. edulis) except PGDc which was only observed in M. desolationis. PGDC was not observed in Charron nor Banyuls, even in the analysis of 60 specimens. Thirty-three electromorphs were observed in the Banyuls population and 31 at Charron (38 different electromorphs in the combined $M$. galloprovincialis and $M$. edulis range). Forty-eight electromorphs are described in Ahmad \& Beardmore (1976) and Skibinski et al. $(1980,1983)$ in the combined $M$. galloprovincialis and $M$. edulis range of electromorphs. The 10 electromorphs not observed in the samples from Charron (M. edulis) and Banyuls (M. galloprovincialis) are described with low frequencies in Skibinski et al. (1980, 1983).

To summarize Table 1, all the electromorphs found in Mytilus desolationis are unambiguously identified in the combined $M$. edulis and $M$. galloprovincialis range of electromorphs, except PGD c. Therefore, there are no new electromorphs in the $M$. desolationis populations in the study of 1000 individuals. However 9 of the detected electromorphs in our samples of $M$. galloprovincialis and $M$. edulis or 19 of the electromorphs previously described in the literature are lacking in the M. desolationis samples.

\section{Allozyme frequency variations}

Identification of the electromorphs of Mytilus desolationis within the combined range of $M$. edulis and M. galloprovincialis allows a comparison among allozyme frequencies at 10 loci in populations of the 3 forms (Table 2). Three loci were found to be monomorphic: GPD, TO and XDH. Four were weakly polymorphic (the frequency of the second allozyme is lower than 0.05): GOT1, GOT2, MDH1 and MDH2. Five were polymorphic: LAP1, LAP2, PGD, PGI and PGM. At PGD (see above: PGDc) and at GOT1 and GOT2 (see Table 1) some rare allozymes cited in the literature were pooled in an artificial allozyme in Table 2. MDH1 and $\mathrm{MDH} 2$ were not used in the allozyme frequency comparison because data were not given for all the populations in Skibinski et al. $(1980,1983)$. The electromorphs lacking in Kerguelen were always the rare allozymes of $M$. edulis and $M$. galloprovincialis, but one rare 'northern' allozyme, LAP1 d, was rare in $M$. edulis and $M$. galloprovincialis $(p=0.032)$ but appeared more commonly in the Kerguelen Mytilus ( $p=0.365$ in Larose) .

Correspondence analysis gives a representation of all the localities in the multidimensional space of allozyme frequencies (Fig. 1A,B). The 3 first axes of inertia represent $86.3 \%$ of the total amount of the variations occurring in Table 2 (50.3, 29.9 and $6.1 \%$ respectively).

Axis I isolates in negative values the 3 Mytilus galloprovincialis populations and in positive values the 6 other populations. Such differentiation is due, in the order of decreasing contribution, to: (1) high frequencies at LAP $1 \mathrm{f}$ and LAP 1 e in $M$. galloprovincialis versus low frequencies or absence in $M$. edulis and $M$. desolationis; (2) high frequencies at PGI e in $M$. desolationis and $M$. edulis versus low frequencies or absence in $M$. galloprovincialis; (3) at a much lower level, the presence or absence of some rare allozymes such as GOT2 'a-c', LAP2e, PGIf and PGIg, in the different forms.

Axis II distinguishes the 2 Kerguelen populations from the 7 others. Such distinction is mainly due to PGM d and LAP1 b which exhibit great variations but have higher frequencies in Kerguelen than in Mediterranean or Atlantic populations. Two other allozymes contribute to distinguish the populations on Axis II: LAP1 d, rare in $M$. galloprovincialis and $M$. edulis, has higher frequencies (around 0.35) in $M$. desolationis; LAP1 $\mathrm{c}$ shows high frequencies in $M$. edulis (around 0.75), lower in $M$. desolationis (around 0.19 ) and is rare in $M$. galloprovincialis. Axis III separates the different populations within each form in 3 parallel sets, the populations from Bossière, Woods Hole and Venice in the positive values; those of Larose, Wales and Gibraltar in the negative values 
Table 1. Mytilus. Comparison of the electromorphs observed in samples of $M$. desolationis from Kerguelen, $M$. galloprovincialis from Banyuls (Mediterranean) and $M$. edulis from Charron (Atlantic), in the present study. Identification of these electromorphs to the nomenclatures of Ahmad et al. (1976) and Skibinski et al. $(1980,1983)$. Ne: number of electromorphs observed in each species.

$\mathrm{Nt}$ : number of electromorphs observed in the combined $M$. edulis and $M$. galloprovincialis range of electromorphs

\begin{tabular}{|c|c|c|c|c|c|c|}
\hline Locus & \multicolumn{3}{|c|}{ Present study } & $\begin{array}{c}\text { Ahmad } \\
\text { et al. (1976) }\end{array}$ & $\begin{array}{l}\text { Skibinski } \\
\text { et al. (1980) }\end{array}$ & $\begin{array}{l}\text { Skibinski } \\
\text { et al. (1983) }\end{array}$ \\
\hline GPD a & a & a & a & 1 & & \\
\hline GOT1 a & - & - & $a^{*}$ & & 94 & 7 \\
\hline$b$ & $\mathrm{~b}$ & $b$ & $\mathrm{~b}$ & & 100 & 8 \\
\hline c & c & $c^{\circ}$ & $-\cdot$ & & $108-116$ & \\
\hline GOT2 a & - & $-\cdot$ & $-\cdot$ & & $84-94-97$ & \\
\hline$b$ & $\mathrm{~b}$ & $\mathrm{~b}$ & $\mathrm{~b}$ & & 100 & \\
\hline c & c & $\mathrm{C}$ & - & & 108 & \\
\hline LAP1 a & $a$ & - & a & & 93 & 8 \\
\hline $\mathrm{b}$ & $\mathrm{b}$ & $\mathrm{b}$ & b & & 96 & 9 \\
\hline $\mathrm{c}$ & C & C & c & & 100 & 10 \\
\hline d & d & d & - & & 102 & 11 \\
\hline $\mathrm{e}$ & e & e & e & & 104 & 12 \\
\hline $\mathrm{f}$ & - & $\mathrm{f}$ & - & & 108 & 13 \\
\hline$g$ & - & $g^{\circ}$ & - & & 110 & 14 \\
\hline LAP2 a & - & - & a & 1 & 90 & 8 \\
\hline $\mathrm{b}$ & $\mathrm{b}$ & $b$ & b & 2 & 95 & 9 \\
\hline $\mathrm{C}$ & c & c & c & 3 & 100 & 10 \\
\hline d & d & $\mathrm{d}$ & $\mathrm{d}$ & 4 & 105 & 11 \\
\hline $\mathrm{e}$ & - & $-\cdot$ & - & 5 & 108 & 12 \\
\hline MDH1 a & - & - & $a$ & & & \\
\hline $\mathrm{b}$ & b & $b$ & $\mathrm{~b}$ & & & \\
\hline C & c & c & c & & & \\
\hline MDH2 a & a & $a$ & $a$ & & & \\
\hline $\mathrm{b}$ & $\mathrm{b}$ & $b$ & $\mathrm{~b}$ & & & \\
\hline PGD a & a & a & a & & $92-95-97$ & $5-6$ \\
\hline $\mathrm{b}$ & b & $b$ & b & & 100 & 7 \\
\hline c & c & $-\cdot$ &.- & & $105-107-111$ & $8-9-10$ \\
\hline PGI a & a & - & $\mathrm{a}$ & 1 & 80 & 5 \\
\hline $\mathrm{b}$ & - & $b$ & - & 2 & 85 & 6 \\
\hline c & c & c & c & 3 & 90 & 7 \\
\hline d & $\mathrm{d}$ & d & $\mathrm{d}$ & 4 & 93 & 8 \\
\hline $\mathrm{e}$ & e & e & $\mathrm{e}$ & 5 & 100 & 10 \\
\hline $\mathrm{f}$ & - & $\mathrm{f}$ & - & 6 & 105 & 11 \\
\hline g & - & g & $\mathrm{g}$ & 7 & 110 & 12 \\
\hline PGM ${ }^{9}$ & - & a & a & 1 & 92 & 8 \\
\hline$b$ & $\mathrm{~b}$ & b & b & 2 & 96 & 9 \\
\hline $\mathrm{C}$ & c & c & c & 3 & 100 & 10 \\
\hline $\mathrm{d}$ & d & d & d & 4 & 104 & 11 \\
\hline e & - & e & e & 5 & 107 & 12 \\
\hline TO a & $\mathrm{a}$ & a & a & 1 & & \\
\hline $\mathrm{XDH}$ a & $\mathrm{a}$ & $a$ & a & 1 & & \\
\hline $\mathrm{Ne}$ : & 29 & 33 & 31 & & & \\
\hline $\mathrm{Nt}:$ & & & & & 48 & \\
\hline
\end{tabular}

and those of Black Sea, New Bristol and Long Island in the middle. The highest contributions to this axis are given by LAP2 b, PGMb and PGIe. Some rare allozymes such as PGIf, PGIg, PGD 'c', PGMa, PGMe and LAP2 a make a smaller contribution to such differentiation. Within each form, LAP2 $b$ and
PGM $b$ show high frequencies in Bossière, Woods Hole and Venice and low in Larose, Wales and Gibraltar.

To summarize Fig. 1, 2 levels of allozymic variations are observed among the 9 populations studied: 1 level corresponding to Axis I and II (Fig. 1a), where each 
Table 2. Mytilus. Allozyme frequencies in 9 populations of the genus at 10 loci. In $M$. galloprovincialis and $M$. edulis, data are given from Skibinski et al. $(1980,1983)$. At GOT1, GOT2 and PGD, some very rare allozymes were pooled in artificial allozymes shown in inverted commas

\begin{tabular}{|c|c|c|c|c|c|c|c|c|c|}
\hline \multirow[t]{2}{*}{ Locus } & \multicolumn{2}{|c|}{$\begin{array}{l}\text { M. desolationis } \\
\text { Kerguelen Islands }\end{array}$} & \multicolumn{3}{|c|}{$\begin{array}{l}\text { M. galloprovincialis } \\
\text { Mediterranean Sea }\end{array}$} & \multicolumn{4}{|c|}{$\begin{array}{l}\text { M. edulis } \\
\text { Atlantic Ocean }\end{array}$} \\
\hline & Bossière & Larose & Venice & Gibraltar & Black S. & Long I. & Woods $\mathrm{H}$ & N. Bristol & Wales \\
\hline GPD a & 1.000 & 1.000 & 1.000 & 1.000 & 1.000 & 1.000 & 1.000 & 1.000 & 1.000 \\
\hline Gor1 a & 1.000 & 1.000 & 0.839 & 0.944 & 0.936 & 0.944 & 0.950 & 0.933 & 0.953 \\
\hline$b-c c^{\prime}$ & 0.000 & 0.000 & 0.161 & 0.056 & 0.064 & 0.056 & 0.050 & 0.067 & 0.047 \\
\hline GOT2 b & 1.000 & 1.000 & 0.975 & 0.989 & 0.978 & 0.994 & 1.000 & 1.000 & 0.987 \\
\hline$a-c^{\prime}$ & 0.000 & 0.000 & 0.025 & 0.011 & 0.022 & 0.006 & 0.000 & 0.000 & 0.013 \\
\hline LAP1 a & 0.000 & 0.013 & 0.000 & 0.000 & 0.000 & 0.025 & 0.000 & 0.033 & 0.019 \\
\hline $\mathrm{b}$ & 0.455 & 0.417 & 0.000 & 0.028 & 0.010 & 0.051 & 0.117 & 0.150 & 0.198 \\
\hline c & 0.192 & 0.199 & 0.032 & 0.000 & 0.060 & 0.899 & 0.867 & 0.817 & 0.724 \\
\hline d & 0.353 & 0.365 & 0.032 & 0.000 & 0.040 & 0.000 & 0.000 & 0.000 & 0.006 \\
\hline e & 0.000 & 0.006 & 0.468 & 0.361 & 0.300 & 0.013 & 0.012 & 0.000 & 0.049 \\
\hline f & 0.000 & 0.000 & 0.435 & 0.611 & 0.510 & 0.006 & 0.000 & 0.000 & 0.004 \\
\hline g & 0.000 & 0.000 & 0.032 & 0.000 & 0.080 & 0.006 & 0.000 & 0.000 & 0.023 \\
\hline LAP2 a & 0.000 & 0.000 & 0.000 & 0.000 & 0.000 & 0.006 & 0.000 & 0.000 & 0.014 \\
\hline b & 0.421 & 0.211 & 0.042 & 0.000 & 0.010 & 0.106 & 0.433 & 0.130 & 0.140 \\
\hline c & 0.536 & 0.500 & 0.518 & 0.480 & 0.710 & 0.388 & 0.317 & 0.280 & 0.602 \\
\hline d & 0.043 & 0.289 & 0.363 & 0.480 & 0.200 & 0.475 & 0.250 & 0.580 & 0.229 \\
\hline e & 0.000 & 0.000 & 0.077 & 0.040 & 0.080 & 0.025 & 0.000 & 0.010 & 0.016 \\
\hline PGD 'a' & 0.010 & 0.010 & 0.035 & 0.062 & 0.000 & 0.019 & 0.000 & 0.017 & 0.028 \\
\hline $\mathrm{b}$ & 0.810 & 0.970 & 0.890 & 0.900 & 0.990 & 0.963 & 1.000 & 0.950 & 0.950 \\
\hline$' c '$ & 0.180 & 0.030 & 0.090 & 0.040 & 0.010 & 0.019 & 0.000 & 0.033 & 0.020 \\
\hline PGI a & 0.080 & 0.060 & 0.009 & 0.013 & 0.000 & 0.056 & 0.083 & 0.090 & 0.013 \\
\hline b & 0.000 & 0.000 & 0.022 & 0.050 & 0.030 & 0.156 & 0.167 & 0.190 & 0.033 \\
\hline c & 0.280 & 0.120 & 0.801 & 0.544 & 0.780 & 0.344 & 0.417 & 0.380 & 0.247 \\
\hline d & 0.390 & 0.360 & 0.142 & 0.344 & 0.180 & 0.138 & 0.067 & 0.090 & 0.049 \\
\hline e & 0.250 & 0.460 & 0.024 & 0.044 & 0.010 & 0.300 & 0.250 & 0.240 & 0.599 \\
\hline f & 0.000 & 0.000 & 0.000 & 0.006 & 0.000 & 0.000 & 0.017 & 0.000 & 0.000 \\
\hline g & 0.000 & 0.000 & 0.022 & 0.000 & 0.000 & 0.006 & 0.000 & 0.010 & 0.000 \\
\hline PGM a & 0.000 & 0000 & 0.109 & 0.005 & 0.010 & טิ.งิติธ & 0.000 & 0.020 & 0.009 \\
\hline b & 0.140 & 0.060 & 0.318 & 0.111 & 0.190 & 0.144 & 0.117 & 0.070 & 0.106 \\
\hline c & 0.430 & 0.490 & 0.479 & 0.611 & 0.490 & 0.769 & 0.683 & 0.810 & 0.653 \\
\hline$d$ & 0.430 & 0.450 & 0.089 & 0.244 & 0.300 & 0.075 & 0.200 & 0.070 & 0.220 \\
\hline e & 0.000 & 0.000 & 0.005 & 0.028 & 0.010 & 0.006 & 0.000 & 0.030 & 0.011 \\
\hline TO & 1.000 & 1.000 & 1.000 & 1.000 & 1.000 & 1.000 & 1.000 & 1.000 & 1.000 \\
\hline $\mathrm{XDH}$ & 1.000 & 1.000 & 1.000 & 1.000 & 1.000 & 1.000 & 1.000 & 1.000 & 1.000 \\
\hline
\end{tabular}

form is isolated one from another, and 1 level corresponding to Axis III (Fig. 1b) where the variations observed at 3 allozymes contribute to a parallel differentiation within each species

\section{Genetic distances}

The matrix of genetic distances is given in Table 3. The theoretical maximum for Euclidean distance at 10 loci is $D=4.472$ for populations fixed for alternate allozymes on each locus. The highest distance (Larose-Venice, $D=1.3169$ ) represents $29 \%$ of the maximum. The lowest value is obtained between New Bristol and Long Island (0.2419) and represents $5 \%$ of the maximum. The dendrogram (Fig. 2) gives a rep- resentation of the matrix of distances. In the dendrogram, 3 groups are distinguished at the same level (around 0.5): (1) the 3 Mediterranean populations of Mytilus galloprovincialis where Venice is closer to the Black Sea $(D=0.4599)$ than Gibraltar $(D=0.5424)$; (2) the 3 American populations of $M$. edulis, where Long Island is closer to New Bristol ( $D=0.2419)$ than Woods Hole $(D=0.4577)$; (3) the 2 Kerguelen populations of $M$. desolationis - Bossière and Larose $(D=$ 0.4871 ).

The population from Wales is related to the American group at a higher level (0.6202), this level corresponding to the Atlantic Mytilus edulis group. The $M$. desolationis specimens are a little less differentiated $(D=$ 1.0113) from the Atlantic $M$. edulis group than from $M$. galloprovincialis $(D=1.2742)$. 


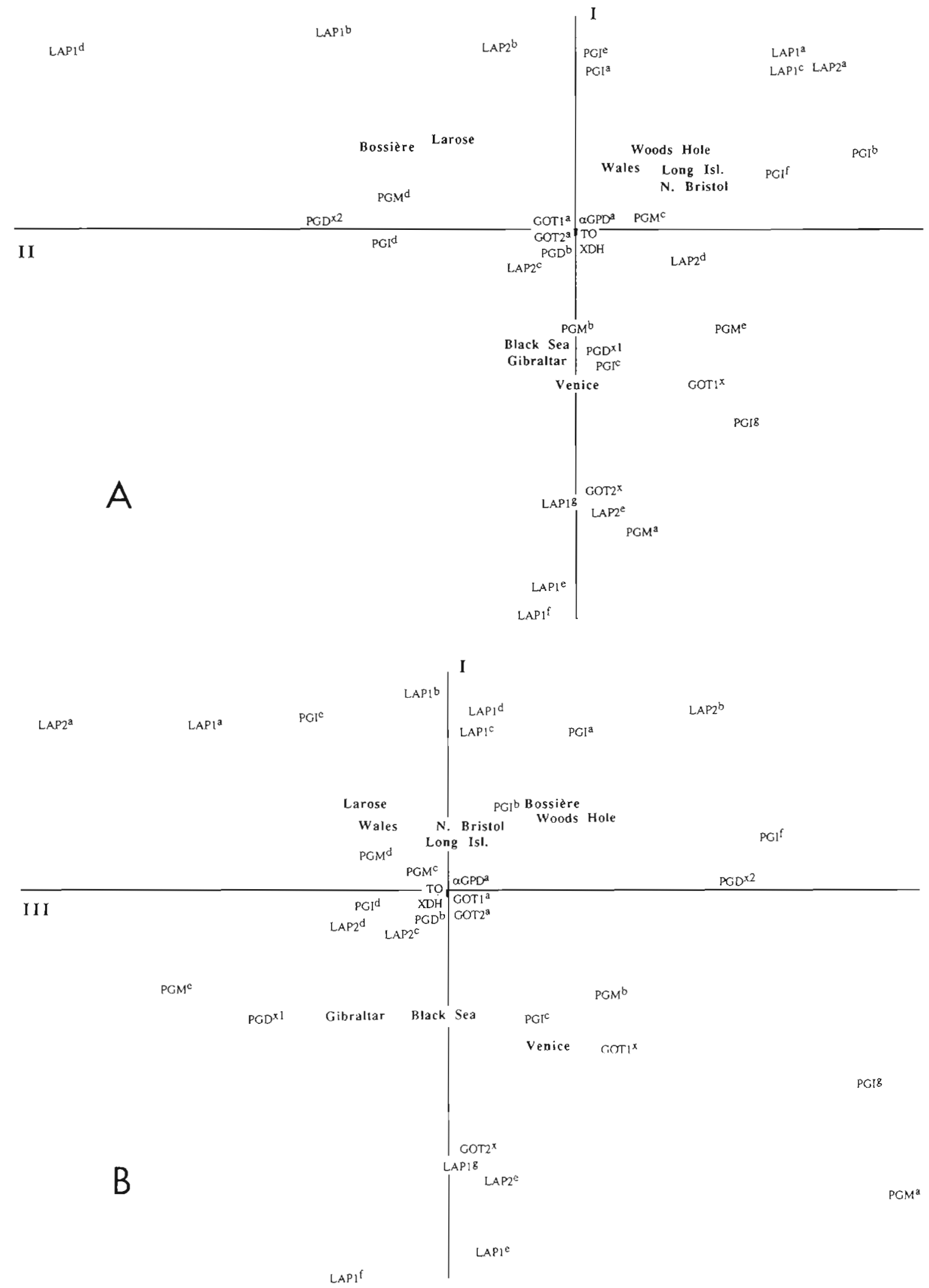

Fig. 1. Correspondence analysis of data given in Table 2. Each population or allozyme is described with its correlation to each axis (angle between axis and vector of the point) and its contribution (projection on the axis of the distance from origin to the point). (A) Axes I and II; (B) Axes I and III 
Table 3. Mytilus. Euclidean distances $D$ estimated from data given in Table 2 among 9 populations of $M$. desolationis, $M$. galloprovincialis and $M$. edulis. D can range between 0 (identical frequencies) to 4.47 (no electromorph in common)

\begin{tabular}{|c|c|c|c|c|c|c|c|c|}
\hline & Larose & Venice & Gibraltar & Black S. & Long I. & Woods $\mathrm{H}$. & N. Bristol & Wales \\
\hline Bossière & 0.4871 & 1.2719 & 1.2032 & 1.1632 & 1.2202 & 1.0621 & 1.2308 & 0.9906 \\
\hline Larose & & 1.3170 & 1.1572 & 1.2113 & 1.0945 & 1.0539 & 1.1001 & 0.8350 \\
\hline Venice & & & 0.5425 & 0.4600 & 1.2837 & 1.3048 & 1.2782 & 1.3050 \\
\hline Gibraltar & & & & 0.5299 & 1.2406 & 1.3029 & 1.2195 & 1.2683 \\
\hline Black S. & & & & & 1.2918 & 1.2789 & 1.3149 & 1.2350 \\
\hline Long I. & & & & & & 0.4577 & 0.2419 & 0.5672 \\
\hline Woods Hole & & & & & & & 0.5011 & 0.6138 \\
\hline N. Bristol & & & & & & & & 0.6860 \\
\hline
\end{tabular}

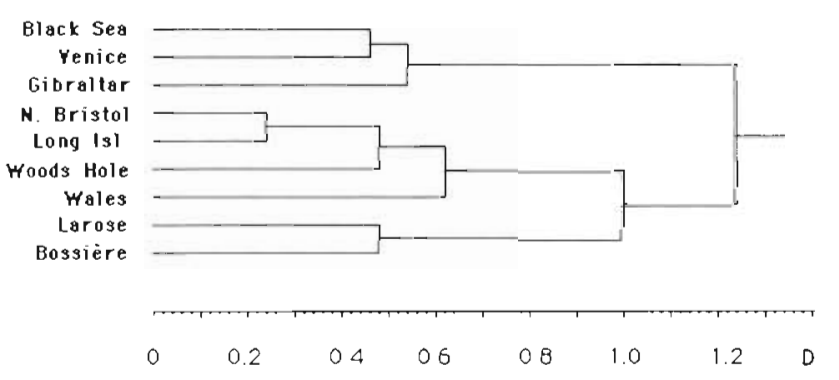

Fig. 2. Dendrogram of unweighted pair-group arithmetic average cluster analysis (UPGMA) of the matrix of Euclidean distances given in Table 3. $D$ ranges between 0 for identical populations to a theoretical maximum of 4.47 when no electromorph is in common between 2 populations

\section{DiSCUSSION}

Comparison of electrophoretic data among Mytilus desolationis, $M$. edulis and $M$. galloprovincialis shows close relationships. Out of 29 electromorphs observed in Kerguelen at the 12 loci investigated, 28 are unambiguously identified in the combined $M$. galloprovincialis and $M$. edulis range of electromorphs. Only 1, PGD c, was detected in $M$. desolationis but not in in our samples of $M$. galloprovincialis and $M$. edulis. However, Skibinsky et al. (1983) described 3 rare allozymes in European Mytilus, PGD 105, 107 and 111, where PGD 107 has an equivalent mobility to PGDc. Thus, we consider that PGD c from M. desolationis is PGD 107. Therefore, no diagnostic locus, as defined by Avise (1974), has been found in our study and this places $M$. desolationis below the species rank. In addition, genetic distances calculated between the 2 populations of $M$. desolationis, the 3 of $M$. galloprovincialis and the 4 of $M$. edulis reveal quite similar values between the Kerguelen group, the Mediterranean group and the Atlantic group (Fig. 2). Yet genetic distance between $M$. desolationis and $M$. edulis from Wales is lower than that between $M$. galloprovincialis and $M$. edulis from Wales $(D=0.9128$ and $D=1.2692$, respectively).
According to Gosling (1984), M. galloprovincialis does not show sufficient specific characters to merit the rank of full species. Our data lead to the same conclusion for M. desolationis.

Nevertheless, in terms of number of electromorphs at 12 loci, Mytilus desolationis shows a reduced polymorphism compared to either $M$. edulis or $M$. galloprovincialis. Only 29 standard electromorphs were detected in the study of 1000 specimens of $M$. desolationis while more electromorphs were observed in the combined $M$. edulis and $M$. galloprovincialis range of electromorphs: 38 in the small sample size of this study or 48 in the larger investigations of Ahmad \& Beardmore (1976) and Skibinski et al. (1980, 1983). The undetected electromorphs in $M$. desolationis are rare in European or American Mytilus and it is likely that they are really lacking due to the sample size of 1000 individuals which implies that an electromorph occuring at a frequency higher than 0.000025 (as an heterozygote) may be detected at the $95 \%$ level. According to the Island Model of Slatkin (1981), at such frequency, to be maintained, a rare allozyme is more sensitive to gene flow than selection intensity or mutation rate. In $M$. desolationis, the loss of electromorphs can be accounted for more by a founder effect at the time of colonization than by further selection, because the missing electromorphs lack at all, or nearly all, the polymorphic loci. At present, one may consider that the loss of these electromorphs indicates the absence of gene flow (Buroker 1984, Slatkin 1985a, b) into $M$. desolationis. However, we cannot make the assumption that a true genetic barrier does exist between $M$. desolationis and one or the other mussel form. Karyotypic differences were demonstrated among $M$. desolationis, $M$. edulis and $M$. galloprovincialis (Thiriot-Quiévreux 1984), but Lubet et al. (1984) considered that these karyotypic differences do not constitute a genetic barrier between $M$. edulis and $M$. galloprovincialis. Hybridizations and introgression occur at varying rates between sympatric populations of $M$. edulis and $M$. galloprovincialis (Skibinski et al. 1978, Gosling \& Wil- 
kins 1981), even if these 2 forms have been separated since the Pleistocene (Barsotti \& Meluzzi 1968).

In spite of that, external gene flow would be limited or absent in Kerguelen populations because of physical barriers. According to Arnaud (1974), west to east migration is possible by transport on drifting kelps in Western circumpolar currents. However, this route has not been, apparently, successful in introducing many rare electromorphs into Kerguelen. The $3500 \mathrm{~km}$ distance from continental land masses, but more probably the Antarctic convergence, located to the north of Kerguelen (Gamberoni et al. 1982, Jacques \& Treguer 1986), are strong physical barriers and limit north-south migrations. Therefore, Mytilus desolationis, because of its reduced polymorphism and its geographic isolation, should be considered as a semi-species (see Mayr 1970) of the super-species $M$. edulis until speciesspecific characters are found or the presence of gene flow is demonstrated. This placement of $M$. desolationis is in agreement with the previously held idea of a large $M$. edulis complex with different lineages showing different levels of evolutionary divergence (Gosling 1984, Koehn et al. 1984, Varvio, Koehn \& Vainola pers. comm.).

Analysis of allozyme frequency variations reveals that the frequencies are not randomly distributed between the localities studied. Axes I and II of the correspondence analysis distinguish the 3 main groups of Mytilus desolationis, $M$. edulis and $M$. galloprovincialis but Axis III sets appart different locations of the same form (Fig. 1A,B). These variations occurring on Axis III are corroborated by the genetic distances between the localities within the same form. These genetic distances are not correlated to the geographical distances, $d$ (Long Island-Woods Hole, $D=0.4577, d=$ $300 \mathrm{~km}$; Gibraltar-Venice, $D=0.5425, d=3000 \mathrm{~km}$; Bossière-Larose, $D=0.4871, d=80 \mathrm{~km}$ ). The environment at which samples are collected has been demonstrated to be the most important factor for the estimates of among-locality genetic heterogeneity (Balagot 1971, Levinton \& Suchanek 1978). For instance, a cline of allozyme frequencies is described in North American populations of Mytilus from north to south: 'here natural selection operates on different genotypes within a species or between individuals of two differing species' (Koehn et al. 1984). In Long Island Sound, at the LAP locus, the molecular mechanism of genotypic adaptation to environment (salinity and temperature) has been demonstrated (Koehn et al. 1976, 1980, Koehn 1983, Hilbish 1985, Hilbish \& Koehn 1985). In a small embayment, St Margaret's Bay (Nova Scotia), GartnerKepkay et al. (1983) described how genetic differentiation occurs even in the face of gene flow. The correspondence analysis suggests that the same allozymes at the LAP locus are involved in the parallel differentia- tion within $M$. desolationis, $M$. galloprovincialis and $M$ edulis (at least between Long Island, New Bristol and Woods Hole) and that the same molecular mechanisms may occur within each taxon. The level of local differentiation between neighboring populations, previously observed in Kerguelen (Blot et al. 1987), may indicate that, because of the large variety of biotopes of these islands (Arnaud 1974, Lawrence et al. 1987), populations of Mytilus are subjected to higher selective forces and/or greater isolation from one another. An analysis of a large collection from populations occurring in a variety of environments is presently underway to test these hypothetical statements.

Acknowledgements. This work was sponsored by TAAF (French Austral and Antarctic Territories). Thanks to E. Gosling, R. S. Scheltema and R. Vainola for constructive com ments and $\mathrm{G}$. Bouyé for providing Mytilus edulis specimens.

\section{ITIERATURE CITED}

Ahmad, M., Beardmore, J. A. (1976). Genetic evidence that the 'Padstow' mussel is Mytilus galloprovincialis. Mar. Biol. 35: 139-147

Ahmad, M., Beardmore, J. A., Skibinski, D. O. F. (1977). An estimate of the amount of genetic variation in the common mussel Mytilus edulis. Biochem. Genet. 15: 833-846

Arnaud, P. M. (1974). Contribution à la bionomie benthique des régions Antarctique et Subantarctique. Tethys 6 : $465-653$

Avise, J. C. (1974). Systematic value of electrophoretic data Syst. Zool. 23: 465-481

Balagot, B. P. (1971). Microgeographic variation at two biochemical loci in the blue mussel, Mytilus edulis. M. A thesis, Stony Brook Univ., New York

Barsotti, G., Meluzzi, C. (1968). Osservazioni su Mytilus edulis L. e Mytilus galloprovincialis Lmk. Conchiglie 4: 50--58

Benzecri, P. (1969). Statistical analysis as a tool to make patterns emerge from data. In: Watanabe, S. (ed.) Methodologies of pattern recognition. Academic Press, New York, p. 35-60

Blot, M., Soyer, J., Thiriot-Quiévreux, C. (1987). Preliminary data on the genetic differentiation of Mytilus desolationis Lamy 1936 and Aulacomya ater regia Powell 1957 (Bivalvia Mytilidae) in the Kerguelen Islands (TAAF). Polar Biol. 7: 1-9

Brewer, G. J. (1970). An introduction to isozyme techniquues. Academic Press, New York

Buroker, N. E. (1984). Gene flow in mainland and insular populations of Crassostrea (Mollusca). Biol. Bull. mar biol. Lab., Woods Hole 166: 550-557

Chardy, P. (1980). L'espèce et la taxinomie numérique. In: Bocquet, C., Génermont, J., Lamotte, M. (eds.) Le polymorphisme dans le règne animal. Mém. Soc. Zool. Fr. 40: 65-95

Fletcher, H. O. (1938). Marine tertiary fossils and a description of a recent Mytilus from Kerguelen Islands. B. A. N. Z. Antarctic Research Expeditions 1929-1931, Rep. Ser. A 2: $101-116$

Gamberoni, L., Geronimi, J,, Jeannin, P. F., Murasl, J. F. (1982). Study of frontal zones in the Crozet-Kerguelen region. Oceanologica Acta 5: 289-299 
Gartner-Kepkay, K. E., Dickie, L. M., Freeman, K. R., Zouros, E. (1980). Genetic differences and environments of mussel populations in the maritime provinces. Can. J. Fish. aquat. Sci. 37: $775-782$

Gosling, E. (1984). The systematic status of Mytilus galloprovincialis in western Europe: a review. Malacologia 25: $551-568$

Gosling, E., Wilkins, N. P. (1981). Ecological genetics of the mussel Mytilus edulis and Mytilus galloprovincialis on Irish coasts. Mar. Ecol. Prog. Ser. 4: 221-227

Gregorius, H. R. (1978). The concept of genetic diversity and its formal relationship to heterozygosity and genetic distance. Math. Biosci. 41: 253-271

Guttman, L. (1959). Metricizing rank ordered or unordered data from a linear factor analysis. Sankhya 21: 257-268

Hilbish, T J. (1985). Demographic and temporal structure of an allele frequency in the mussel Mytilus edulis. Mar. Biol. 86: 163-171

Hilbish, T. J., Koehn, R. K. (1985). The physiological basis of natural selection at the Lap locus. Evolution 39: 1302-1317

Hill, M. O. (1974). Correspondence analysis: a neglected multivariate method. J. R. Stat. Soc. Ser. C 23: 340-354

Jacques, G., Treguer, P. (1986). Ecosystèmes pélagiques marins. Masson, Paris

Katz, M., Goux, J. M. (1986). The statistical properties of genetic absolute distance. Biom. J. 28: 729-739

Koehn, R. K. (1983). The biochemical and physiological bases of amino-peptidase-I (LAP) polymorphism in Mytilus edulis. In: King, C. E., Dawson, P. S. (eds.) Population biology. Columbia University Press, New York, p. 117-146

Koehn, R. K., Hall, J. G. Innes, D. J., Zera, A. J. (1984). Genetic differentiation of Mytilus edulis in Eastern North America. Mar. Biol. 79: 117-126

Koehn, R. K., Milkman, R., Mitton, J. B. (1976). Population genetics of marine Pelecypodes IV Selection, migration and genetic differentiation in the blue mussel, Mytilus edulis. Evolution 30: 2-32

Koehn, K. K., Newell, R. I. E., Immerman, F. (1980). Maintenance of an aminopeptidase allele frequency cline by natural selection. Proc. natl Acad. Sci. U.S.A. 77: 5385-5389

Lamy, E. (1936). Révision des mollusques vivants du Muséum National d'Histoire Naturelle de Paris. J. de Conchyliol. $80: 66-102$

Lawrence, J. W., McClintock, J. B. (1987). Intertidal invertebrate and algal communities on the rocky shores of the Bay of Morbihan, Kerguelen (South Indian Ocean). P.S.Z.N.I: Mar Ecol. 8 (3): 207-220

Lebart, L., Fénelon, J. P. (1975). Statistique et informatique appliquées. Dunod, Paris
Levinton, J. S., Suchanek, T H. (1978). Geographic variation, niche breadth and genetic differentiation at different scales in the mussels Mytilus californianus and Mytilus edulis. Mar. Biol, 49: 363-375

Lubet, P., Prunus, P., Masson, M., Bucaille, D. (1984). Recherches expérimentales sur l'hybridation de Mytilus edulis L. et Mytilus galloprovincialis Lmk. (Mollusques Lamellibranches). Bull. Soc. Zool. Fr 109: 87-98

Mayr, E. (1970). Population, species and evolution. Belknap Press of Harvard University, Cambridge, Mass.

Nei, M. (1972). Genetic distance between populations. Am. Nat. 106: 283-292

Rogers, J. (1972). Measures of genetic similarity and genetic distance. Stud. Genet. Tex. U. 7: 145-153

Rogers, J. (1984). Deriving phylogenetic trees from allele frequencies. Syst. Zool. 33:52-63

Rogers, J. (1986). Deriving phylogenetic trees from allele frequencies: a comparison of nine genetic distances. Syst. Zool. 35: 297-310

Skibinski, D. O. F., Ahmad, M., Beardmore, J. A. (1978). Genetic evidence for naturally occuring hybrids between Mytilus edulis and Mytilus galloprovincialis. Evolution 32: 354-364

Skibinski, D. O. F., Beardmore, J. A., Cross, T. F. (1983). Aspects of the population genetics of Mytilus (Mytilidae, Mollusca) in the British Isles. Biol. J. Linn. Soc. 19: $137-183$

Skibinski, D. O. F., Cross, T F., Ahmad, M. (1980). Electrophoretic investigations of systematic relationships in the marine mussels Modiolus modiolus L., Mytilus edulis L., Mytilus galloprovincialis Lmı. (Mytilidae Mollusca). Biol. J. Linn. Soc. 13: 65-73

Slatkin, M. (1981). Estimating levels of gene flow in natural populations. Genetics 99: 323-335

Slatkin, M. (1985a). Gene flow in natural populations. Ann. Rev. Ecol. Syst. 16: 393-430

Slatkin. M. (1985b) Rare alleles as indicators of yeñe flow Evolution 39: 53-65

Sneath, P. H. A., Sokal, R. R. (1973). Numerical taxonomy. Freeman, San Francisco

Sokal, R. R., Rohlf, F. J. (1963). Biometry. Freeman, San Francisco

Soot-Ryen, T (1955). A report of the family Mytilidae (Pelecypoda). Allan Hancock Pacif. Exped. 20: 1-75

Thiriot-Quiévreux, C. (1984). Chromosome analysis of three species of Mytilus (Bivalvia: Mytilidae). Mar. Biol. Lett. 5 $265-273$

Yagolnitzer, K., Tabet, N. (1985). Software ADDAD. Laboratoire de Statistiques, Université Pierre et Marie Curie, 4, Place Jussieu, F-75005 Paris 